\title{
Power Electronics Converter Application in Traction Power Supply System
}

\author{
Asegid Belay Kebede ${ }^{1, ~ *, ~ G e t a c h e w ~ B i r u ~ W o r k u ² ~}$ \\ ${ }^{1}$ African Railway Ceneter of Excellence, Faculty of Technology, Addis Ababa Institute of Technology, Addis Ababa, Ethiopia \\ ${ }^{2}$ Electrical and Computer Engineering, Faculty of Technology, Addis Ababa Institute of Technology, Addis Ababa, Ethiopia
}

Email address:

assegidjesus@gmail.com (A. B. Kebede),gbiru@yahoo.co.uk (G. B. Worku)

${ }^{*}$ Corresponding author

To cite this article:

Asegid Belay Kebede, Getachew Biru Worku. Power Electronics Converter Application in Traction Power Supply System. American Journal of Electrical Power and Energy Systems. Vol. 9, No. 4, 2020, pp. 67-73. doi: 10.11648/j.epes.20200904.12

Received: January 22, 2020; Accepted: March 5, 2020; Published: August 25, 2020

\begin{abstract}
The electrified railway systems have been spreading all over the world. In big cities, metro or light rail transit railway networks have been constructed extensively. Expansion of this enormous dynamic electric load has been created huge amount of stress on the power grid. Generally, the speed drives, power conversion equipment or frequency converters inject harmonic in to railways power supply system. These harmonics seriously disturbs other electrical systems or generate a high frequency electromagnetic fields in neighboring electrical equipment as well as traction network signaling system. However, new developments in power electronic converter enable efficient and flexible conditioning of electrical energy in the application of railway power system. Power electronics, already previously being a pioneer for progress of traction vehicles, brought forth an ultimate standardization of the traction power supply system. Today, the spectrum of power electronic converters application in the traction system spread in many areas including power electronics based traction transformers, auxiliary power supply systems, rectification, integration of regenerative braking, reactive power compensation and voltage regulation and traction motor controls. This paper reviews the applications of semiconductor based power electronic devices in electrified railway system and illustrates some major application areas.
\end{abstract}

Keywords: Power Electronics, Railway System, Revolution, Traction Transformer

\section{Introduction}

The history of power electronics extends nearly 120 years of age. In 1901, the discovery of glass tube mercury arc rectifier by peter cooper Hewitt of the United States of America gave birth to power electronics [1]. Hot cathode thyratron was introduced in 1926 and the ignitron rectifier in 1933. The 1930s and 1940s became the ages of gas tube electronics and saturable core magnetic amplifiers respectively. The applications of power electronic converters started to spread in the railway industry in 1930 when the New York sub way installs a grid-controlled mercury arc rectifier with a capacity of 3 megawatt for the direct current (DC) drive [6]. Then, the German railways introduced mercury-arc cyclo-convertors for universal motor traction drive system. The above two events are believed to be the first cases which introduced power electronics in the railway systems.
Beginning from 1946 with the inventions of thyristor type devices the modern era of power electronics started [7]. In this era, the evolutions of power electronics can be divided into four generations as shown in Figure 1. The first generation lasted for almost two decades and was dominated by thyristor type power electronic devices and is identified as the era of thyristor. Self-controlled power electronics devices such as BJTs, power MOSFETs, and GTOs outshined in the second generation for a decade. The third generation witnessed the most dominant semiconductor based power electronic device, the IGBT, and setup an important landmark in the history of power electronics. At last, the fourth generation brought new devices such as IGCT, cool MOS and very recently a wideband power devices such as silicon carbide ( $\mathrm{SiC})[2,4,6$, 9]. Fortunately, in parallel with the power semiconductor-evolution, the railway system has been benefited a lot from this technological revolutions.

Today, the scope of power electronics applications in the 
railway system is very extensive. One end of the scope involves in the application of power electronics based traction transformers which exhibits one of the greatest breakthroughs in recent years. The auxiliary power supply system which receives a conditioned electrical signal from the traction transformer via power electronics converters to feed compressors and fans, the air conditioning, heating, lighting, the control for doors and breaking systems and to charge the battery of the vehicle. Modern power compensator are working based on power electronics converters, which helps to improve power factor of the traction power supply system. They are also a very important elements in modern flexible ac transmission systems (FACTS). Power electronics also used in rectification of the $\mathrm{AC}$ power to $\mathrm{DC}$ power in direct current traction system. The traction motor (AC or DC) drives certainly comprises the major area of power electronics applications. Many studies show the use of regenerative braking in railway system for recovering electrical energy saves energy consumption of the system up to $42 \%$ [3] but without power electronics converter this energy recovery mechanism cannot be realized. This paper reviews applications of power electronics devices in railway system and illustrates some major application areas.

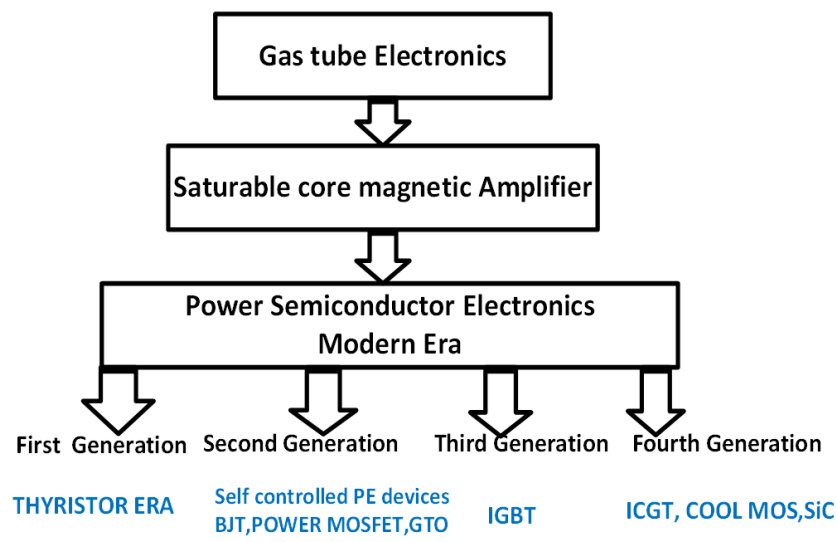

Figure 1. History of evolution of power electronic.

\section{Traction Power Electronics Transformer}

The decrease in the weight by high frequency transformers, market availability and impressively improved semiconductor devices, have led to research in power-electronic transformers that are also discussed in research literature as smart transformers and solid-state transformers $[4,5,6]$. The line frequency transformers as shown in Figure 2 are distributed broadly in electrical power systems environments and also in traction power supply system giving functions such as electrical isolation and voltage conditioning. Nevertheless, to solve problems related to power quality such as harmonics, flicker and sags at MVL (medium voltage levels), there is a requirement for the setting up of extra device commonly a power electronics devices working at high frequencies.

This leads to an increase in the volume of the installed equipment's, which in some applications area may not be feasible especially in traction system. Currently movements in medium voltage high power applications are repeating somewhat technologies that has been already realized and put into practice in low voltage applications areas. Therefore, today there is a trend to replace the conventional line frequency transformers by medium frequency transformers where high frequency signals are directly applied to the terminals of the transformer (traction transformer) as shown in Figure 3 and Figure 4, which in turn decreases the overall magnetic volume of the transformer and leads to more compact power converter devices.

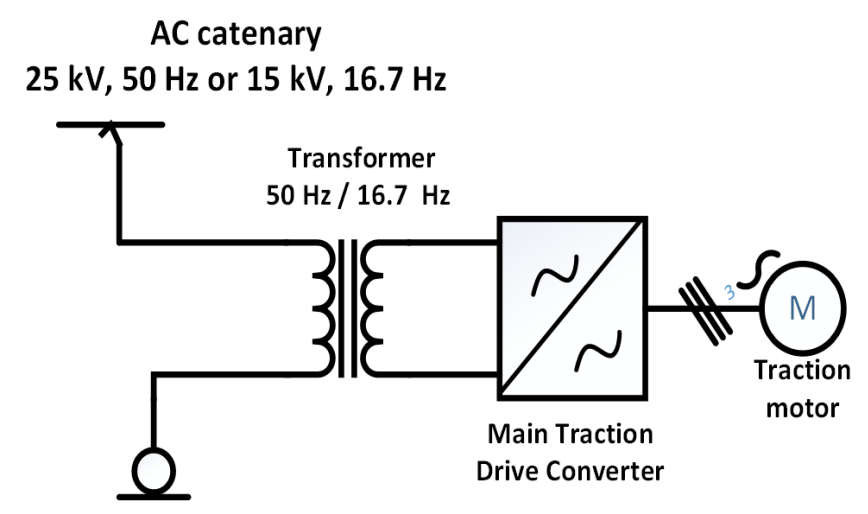

Figure 2. Conventional transformer for traction application [5].

In comparison to $50 \backslash 60-\mathrm{Hz}$ transformers, high-frequency transformers operating at $20 \mathrm{kHz}$, can be significantly reduced and lighter by a factor of 150 as presented in [10]. In addition to that size reduction also shows or implies as a substantial amount of core and copper material saving. It is important to note that, in [11] 90 percent power loss reduction has been reported for the comparable $30 \mathrm{KVA}$ $50 / 60 \mathrm{~Hz}$ line frequency transformer. The iron core of high frequency transformers is made up of a Nano crystalline material such as FINEMET ${ }^{\circledR}[14]$ that is ideal because of its high permeability, high saturation flux-density, and very low core-loss at frequencies of $20 \mathrm{kHz}$.

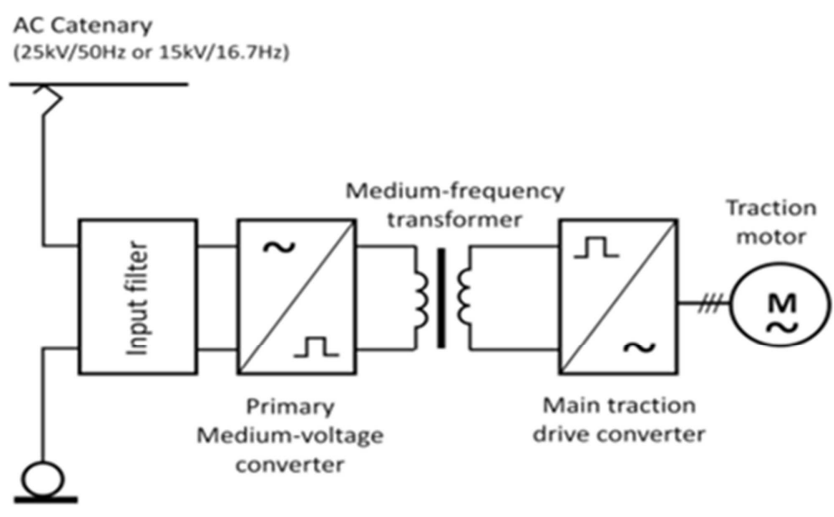

Figure 3. Power electronics transformer for traction application [7].

The cost of material which is required for the production of the power electronics transformer decreases significantly in large volume production. Therefore, it is predictable that the overall losses, including those in power electronic 
converters decreases significantly in any transformer rating. However, in some literatures [12-15] power electronic transformers drawbacks have been reported such as electromagnetic interference and severe stresses on the insulation of the transformer because of high rate of change of voltage during switching, which causes failure in the control circuits and in some auxiliary equipment's inside the train. A serious harmonic problems also reported in [16].

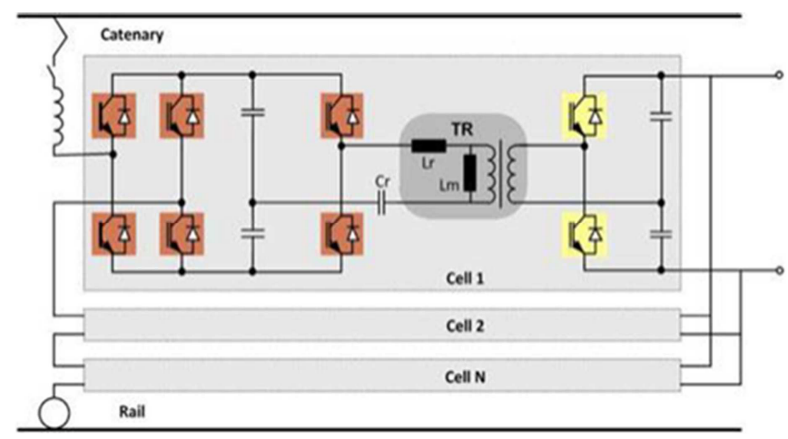

Figure 4. Power electronics transformer for traction application [9].

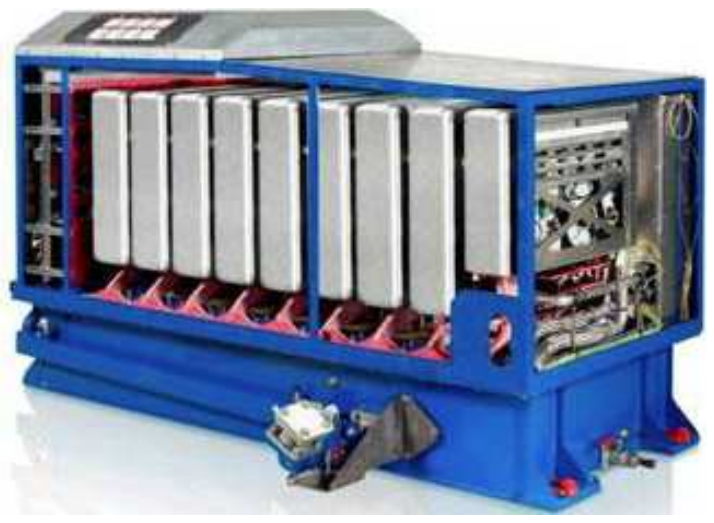

Figure 5. Modularized Power electronics transformer [9].

In [17] switching power loss is reported because of hard switching techniques. In [19] a novel power electronic transformer is introduced by ABB which significantly reduced problems related to power loss and harmonics. Figure 5 shows compacted medium frequency transformer designed specifically for railway application. In this topology in order decrease electromagnetic interference, harmonics and power losses soft switching mechanisms are introduced.

\section{Auxiliary Power Supply System}

Another power electronics application area is the auxiliary power supply system. Auxiliary power supply system is one of the vital components of a trains. Voltage variation of auxiliary power supply system is a significant dynamics which jeopardize the safe operation of traction trains. The motor and auxiliary power supply system in the train are powered by traction transformer which can be either a conventional line frequency transformer or a power electronics transformer. The auxiliary power supply system provides power for all electrical equipment except the traction motor. Its regular and stable work is related to the well-being and comfort of the passengers. So, it plays an important role in a traction train. However, frequent passing neutral section of trains, switching of large loads and other factors will cause voltage fluctuation of the auxiliary power supply system. These will endanger the safe operation of the train. Currently, there are many studies on the normal and steady operations of auxiliary power supply system [21].

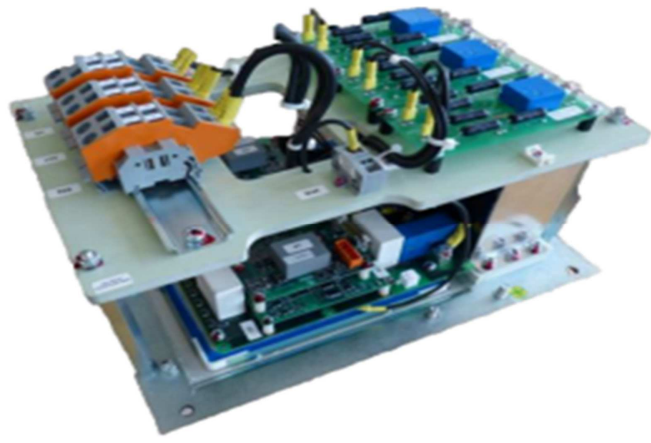

Figure 6. Auxiliary power supply system for railway system [21].

Due to the fact that auxiliary power despite of input voltage fluctuation has to provide a regulated voltage at output, some papers around this purpose are reviewed. [21] Applied the power electronics converter parallel technology to the auxiliary system to increase its reliability and redundancy. In [25] overvoltage of auxiliary power supply system produced by the train while passing neutral section of catenary system has been investigated.

In [20] a technique is laid down to alleviate the overvoltage. In [21] the voltage variation caused by the start of the air conditioning loads in the auxiliary power supply system analyzed and changing the start sequence can mitigate the voltage fluctuation. [22] Describes the IEEE requirements for the passenger train auxiliary power supply system interface. In [23] auxiliary power arrangement in whole train combined of motor cars and passenger cars are clarified. In [24] innovative control approaches suitable for auxiliary power supply system is offered, which aims to accomplish high reliability by redundancy. It gives a power factor of auxiliary power electronics converters high. In this study in order to remove circulating currents between converters, one of them is monitoring its power factor and others follow it as shown in Figure 6. In [25] an isolated full bridge three phase $\mathrm{DC} / \mathrm{DC}$ converter topology is proposed. In this paper the input $\mathrm{DC}$ voltage is inverted to three phase $\mathrm{AC}$ and then is converted to a DC voltage by a full-bridge rectifier. In [26] a novel multi-level DC/DC power electronic converter considered for auxiliary power supply application is proposed. The suggested system is built based on half bridge converter. [27] Introduces a specific prototype of auxiliary power supply system, which has applied IGBT as high power switches. In [28] an adaptive inverse model controller is devised to compensate non-linearity and imperfections of components. Switching strategy is modified PWM to adapt duty cycle with nonlinear and non-ideal system. In [29] a two switch high frequency fly back converter is developed to achieve ZVS. A few modules of proposed converter can be 
paralleled for higher power.

In [30] a phase modulated full-bridge converter is improved to decrease output voltage harmonics and enhance it to show more robustness against input voltage fluctuation. In [31] a ZVS multi-level resonant converter is proposed as well as [32] phase shift modulation is utilized. For ZVS, leakage inductance of transformer is brought into play. In [33] a novel AC three phase input DC output converter is introduced. The previous circuit that the new one is based on three parallel full bridge rectifiers followed by buck-boost converters, which proposed paper merged rectifiers together and uses a single buck-boost converter. [34] Has presented a new scheme for switching which decouples gate switching voltages from input voltage, and then it is a desirable configuration for situations with varying input voltage.

\section{Regenerative Energy}

Numerous researches have shown that the application of regenerative braking in railway systems could actually decrease the net energy consumption up to $42 \%$ depending on the characteristics of the system [35]. Regenerative braking concepts has been extensively utilized in traction system for many years using the train's motors as a generators during barking. Today, the availability of state of the art power electronic switching devices has increased the efficiency of regenerative braking in traction system. Cities such as Hamburg, Caracas, Sao Paulo, Dublin, Vienna and shanghai including Japanese maglev system adopted or integrated regenerative braking into their railway system [36]. This concept has been utilized for many years [37], and with increasing electrification of the railways many new trains have been designed with such systems in mind [38]. The increasing availability of sophisticated power electronic components [39] and improvements in control circuitry [40] has improved the efficiency of regenerative braking on the railways. One article quotes a reduced electrical energy consumption of $37 \%$ [41]. Various computer simulations studies have modelled the effect of regenerative braking on power flow [42] and load flow [43].

In [44] implementation and control of the $\mathrm{AC} / \mathrm{DC} / \mathrm{AC}$ converter, used to connect the flywheel high voltage side to the wheel motor is discussed. Also the converter general operation and the adopted control strategy are presented. The dual-active-bridge (DAB) dc-dc converter is a promising topology for bidirectional applications. The DAB converter was proposed in [45], followed by a detailed investigation in [46] and a series of improvements such as improving the switching conditions [47] and reducing the circulating reactive power [49]. It is also possible to use other switching bridge cells different from a full-bridge. The DAB converter uses phase shifting to control the power flow through a high-frequency transformer. It has been proposed for high power density and high-efficiency dc-dc converting applications. In the category of isolated bidirectional dc-dc converters, several full-bridge derived converter topologies have been proposed in the literature, with the aim to reduce switching loss, minimize electro-magnetic interference (EMI), and increase efficiency [52, 53]. A bidirectional dc-dc converter can be as simple as a two-quadrant buck/boost converter which may fulfill the requirements for interfacing energy storage with a regenerative motors [54, 55]. The converter allows bidirectional power flow and can achieve high efficiency because of low parts count and lack of a transformer. Furthermore, low parts count allows for compact packaging and competitive pricing.

However, the intermittent nature of regenerative energy source in the railway system does not assure a reliable and a continuous source of energy and makes it unsuitable for standalone operation. A common solution to solve this challenge is to use an energy storage device besides the regenerative energy source to compensate for these fluctuations and to make sure a continuous power is flowing to the load. Today, medium range power batteries and super-capacitors are regarded as the most common and economical energy storage devices and power electronic converters are always required to facilitate the flow of electrical energy between the source and the storage devices and also between the storage device and the rest of the system.

\section{Power Electronics Compensator}

Power quality problems which arise because of the very nature of the railway power supply system configuration reduce the efficiency of the other users significantly. The railway load is a single phase load and connecting this highly fluctuating, single- phase and non-sinusoidal traction loads to the grid or the three phase line causes a very serious power unbalance. Various countries use different solution for the existing problems. For example, some countries use by interchanging or sequencing the phase of the grid whether it is two phases or three phases as shown in Figure 7 and Figure 8 below. Other countries isolate the total traction power supply system from the public grid to keep other customers from these enormous power quality disturbances.

Apart from power unbalance the railway system is subject to a very serious harmonics injected to the supply system. This harmonics arise from various equipment's such as speed drives, power conditioning or adaptation equipment's or frequency converters. This harmonics causes a high electromagnetics disturbances to the neighboring electrical equipment's such as signaling devices or systems. Today, in order to solve these problems thanks to technology a power electronics based modern active power filters are available.

Another challenge regarding the railway power supply system power quality problem is flicker, which happens when the train passes between two neighboring substation and to solve these problems in different countries they use different methods. For example in Ethiopia the railway power supply network is connected to high voltage system or building the railway system to work under a higher catenary voltage. 


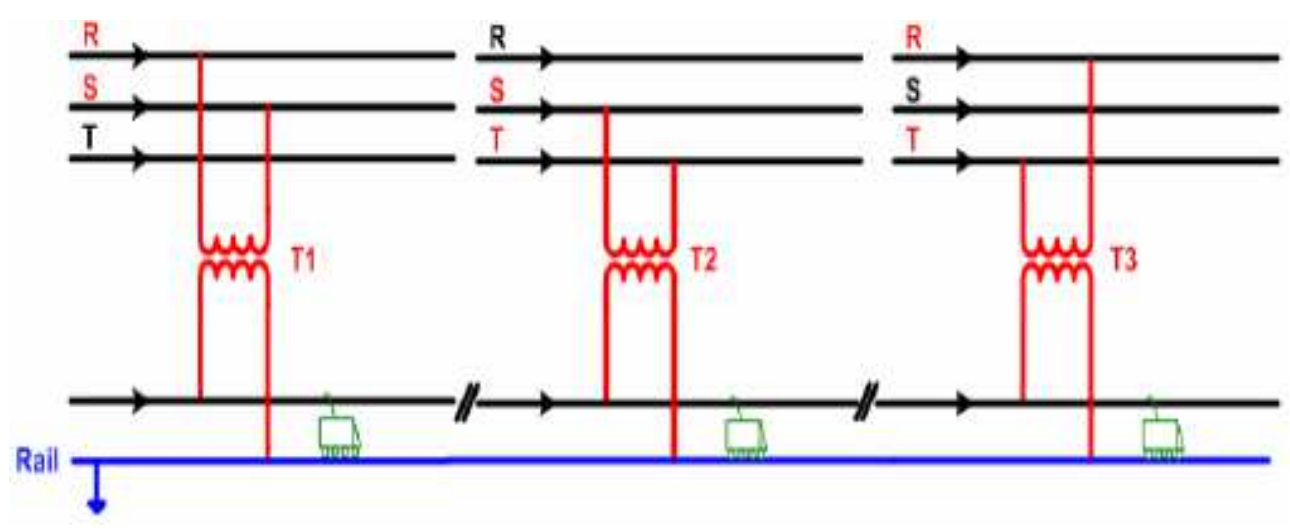

Figure 7. A typical Single phase railway transformer connection with the three phase grid [44].

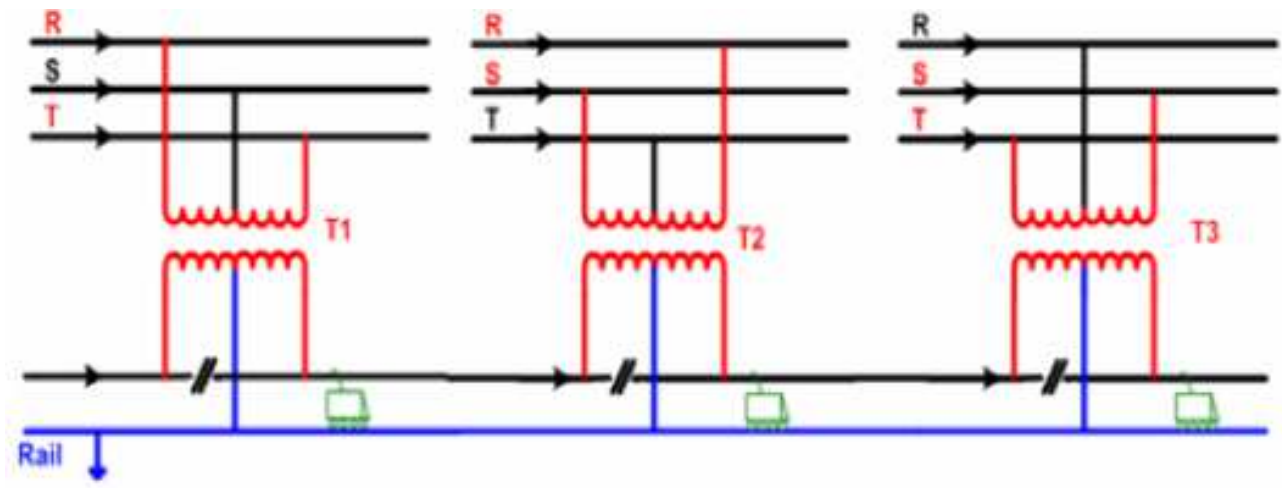

Figure 8. A typical Vv transformer connection with three phase grid [44].

Today power electronics devices become a new solution for power quality problems. To control the voltage form factor of the direct power supply electrified railway system [50] designed, simulated and experimented a novel power electronic compensators. The power electronic compensator presented in the above references are a shunt connected compensator to solve harmonic distortion and low power factor. The shunt compensator is connected at the end of overhead line and operates regarding to the voltage which senses at its connection point.

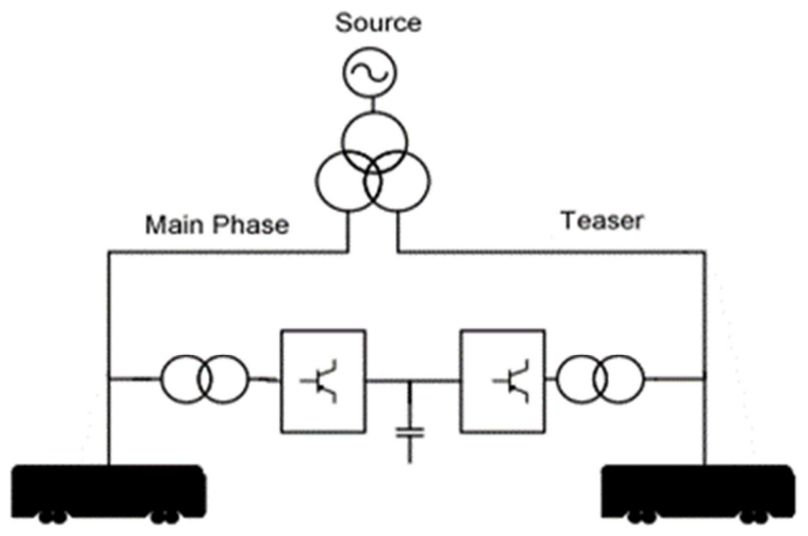

Figure 9. Scott transformer and DC/AC converter for power balance.

In [51] alternative shunt connected power electronics compensator is discussed which deals with unbalance produced by the moving loads apart from reactive power required by traction motor. The technique is improving the conventional traction transformer with a bidirectional inverter that can balance two output phases of the special transformer designed for the railway system called Scott transformer by transferring part of overloaded phase to under loaded one. In this case the inverter compensates harmonics. In [52] has realized same but more advanced strategy for Japanese high speed railway as shown in Figure 9.

A power electronic based system stabilizer for the Korean high speed railway distribution system is applied in [5]. In this presented work the correlation between the stability and power loss in the traction supply system is examined. At the end the study comes to the conclusion that the stability of the system increases by decreasing the voltage drop through reactive power compensation. The stabilizer produces required reactive power. [53] Uses a thyristor which is cheap in comparison with the above discussed references. As a limitation, compensation in this method can be conducted in steps and not continuously and also thyristor is a source of harmonics because of its low switching frequency.

\section{Traction Motor Control}

In the past, both the electrical power system and the main-drive ideas were mainly connected together [54]. For example in some part of Europe such as Austria and Germany $15 \mathrm{kV} 16.7 \mathrm{~Hz}$ traction power system shown largely with transformer, switch-gear and series-wound, 
compensated commutator motors; then in the early seventeen's thyristor control was introduced, which in turn demanded $50 \mathrm{~Hz}$ thyristor phase control and separately excited DC motors. In DC grids, the original camshaft-resistor control of series-wound commutator motors was replaced by thyristor chopper control in the sixties.

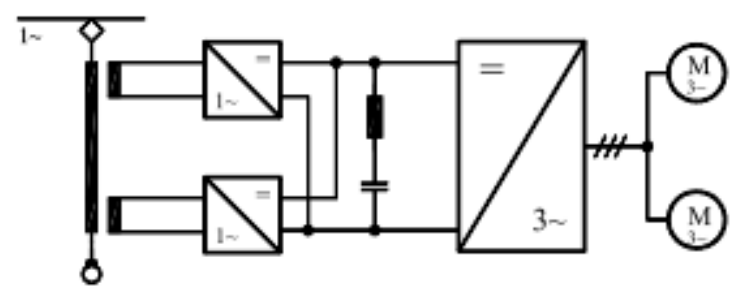

Figure 10. Full-electric locomotive with two Four-Quadrant Converters.

The French high speed railway system TGV-A used synchronous motors, fed by load-commutated thyristor converters [55]. Today drive system with asynchronous motors or squirrel cage induction motors fed by voltage source inverter (VSI) becomes the world standards.

\section{Conclusion}

The intense competition and new formation of railway industry led to numerous ground-breaking designs of electrified railway cars, which of course become attractive for the customer and economic to operate, largely assisted by high-performance power electronic converter and the high degree of modularity. In this paper a history, application and recent trend of power electronic converter in traction power supply system has been reiterated. In brief power electronics traction transformer, traction auxiliary power supply system, regenerative braking, power compensators and traction motor control system have been addressed.

\section{Acknowledgements}

This research was supported by African railway excellence center, Addis Ababa university institute of technology in cooperation with World Bank group.

\section{References}

[1] H. Meniken: "Stromrichtersystem mit wechsel-spannungs-zwischenkreis und seine anwendung in der traktionstechnik" $\mathrm{PhD}$ thesis, Fakultät für Elektrotechnik, RWTH Aachen, Aachen, Germany, 1978.

[2] S. Östlund: "A primary switched converter system for traction applications" PhD thesis, Royal Institute of Technology, KTH, Stockholm, Sweden, 1992.

[3] S. Östlund: "Reduction of transformer rated power and line current harmonics in a primary switched converter system for traction applications", The 5 th European Conf. on Power Electronics and Applications-EPE, Brighton, UK, 1993, pp. 112-119.
[4] P. C. Kjaer, S. Norrga, S. Östlund: "A primary-switched line-side converter using zero-voltage switching”, IEEE Trans. on Industry Applications, Vol. 37, No. 6, 2001, pp. 1824-1831.

[5] N. Hugo, P. Stefanutti, M. Pellerin, A. Akdag: "Power electronics traction transformer", The 12 th European Conf. on Electronics and Applications-EPE, Aalborg, Denmark, 2007, CD- ROM paper: 0715.

[6] A.-C. Rufer, N. Schibli, V. Briguet: "A direct coupled 4-quadrant multilevel converter for $162 / 3 \mathrm{~Hz}$ traction systems", The 6th International Conference on Power Electronics and Variable Speed Drives, Nottingham, UK, 1996, pp. 448-453.

[7] A. Rufer, N. Schibli, C. Chabert, C. Zimmermann: "Configurable front- end converters for multicurrent locomotives operated on $162 / 3 \mathrm{~Hz}$ AC and $3 \mathrm{kV}$ DC systems", IEEE Trans. on Power Electronics, Vol. 18, No. 5, pp. 2003, 1186-1193.

[8] M. Steiner, H. Reinold: "Medium frequency topology in railway applications", The 12 th European Conf. on Power Electronics and Applications-EPE, Aalborg, Denmark, 2007, CD-ROM paper: 0585 .

[9] H. Iman-Eini, Sh. Fahrangi, J. L. Schanen, M. Khakbazan-Fard: "A modular power electronic transformer based on a cascaded H-bridge multilevel converter", Electric Power System Research, vol. 79, no. 12, 2009, pp. 1625-1637.

[10] J. Weigel, A. Nagel, H. Hoffmann: "High voltage IGBTs in medium frequency traction power supply", The 13 th European Conf. on Power Electronics and Applications-EPE, Barcelona, Spain, 2009, CD-ROM paper: 0804.

[11] H. Hoffmann, B. Piepenbreier: "High voltage IGBTs and medium frequency transformer in DC-DC converters for railway applications", International Symposium on Power Electronics, Electrical Drives, Automation and MotionSPEEDAM, Pisa, Italy, 2010, pp. 744-749.

[12] B. Engel, M. Victor, G. Bachmann, A. Falk: “ $15 \mathrm{kV} / 16.7 \mathrm{~Hz}$ energy supply system with medium frequency transformer and 6.5kV IGBTs in resonant operation", The 10 th European Conf. on Power Electronics and Applications-EPE, Toulouse, France, 2003, CD-ROM paper: 1192.

[13] J. Taufiq: "Power electronics technologies for railway vehicles", International Power Conversion Conference-PCC, Nagoya, Japan, 2007, pp. 1388-1393.

[14] M. Mermet-Guyennet: "New power technologies for traction drives", International Symposium on Power Electronics, Electrical Drives, Automation and Motion-SPEEDAM, Pisa, Italy, 2010, pp. 719-723.

[15] M. Glinka, R. Marquardt: "A new AC/AC-multilevel converter family applied to single-phase converter", The 5 th International Conf. on Power Electronics and Drive Systems, PEDS, vol. 1, Singapore, 2003, pp. 16-23.

[16] P. G. E. Vos "The Auxiliary Power System for Double Deck Trains" Auxiliary Power Supplies for Rolling Stock IEE 1992.

[17] D. R. Kelsall "Design Considerations for Static Auxiliary Supplies" Power Engineering Journal 1992.

[18] S. Indarida et al. "A Novel Power Control Method Achieving High Reliability of Auxiliary Power Supply System for Trains" EPE 2005. 
[19] D. Vinnikovz"Isolated DC/DC Converter Topology with Three-Phase Intermediate AC-Link" Baltic Electronics Conference IEEE 2006.

[20] Li Zhonghao "Chinese Railways and New Scientific Technology" Autonomous Decentralized Systems IEEE 2000.

[21] A. S. Hartono et al. "Development of New Drive system of Diesel Electric Multiple Unit (DEMU) for Indonesia Railway" Autonomous Decentralized Systems IEEE 2001.

[22] A. J. Griffin "Methods of Improving the Voltage Regulation on 25kV Electric Railways" Main Line Railway Electrification 1989.

[23] "High-Speed Trains Worldwide" EJRCF 1994.

[24] R. J. Hill "Electric Railway Traction” Part 1\&2 PEJ 1994.

[25] W. Gunselmann "Technology for Increased Energy Efficiency in Railway Systems" EPE 2005.

[26] Pee-Chin Tan et al. "Voltage Form Factor Control and Reactive Power Compensation in a $25 \mathrm{kV}$ Electrified Railway System Using a Shunt Active Filter Based on Voltage Detection" IEEE Trans. on industry applications 2003.

[27] Z. S. Mouneimne et al. "Demonstrating the Electromagnetic Compatibility of a Vehicle-borne Static Converter" Developments in Mass Transit Systems IEE 1998.

[28] B Busco et al. "Digital Control and Simulation for Power Electronic Apparatus in dual Voltage Railway Locomotive" Power Electronics IEEE Trans. 2003.

[29] L. A. M. Van Dongen et al. "Energy-Efficient Driving Patterns in Electric railway Traction" Main Line Railway Electrification 1989.

[30] Ph. Cougnon et al. "The Brussels tramway 2000 with Asynchronous Traction" Power Electronics and Applications EPE 1993.

[31] D. P. Urciuoli and C. W. Tipton, "Development of a $90 \mathrm{~kW}$ bi-directional dc-dc converter for power dense applications," in Proc. IEEE APEC, Dallas, TX, Mar. 2006, pp. 1375-1378.

[32] S. J. Kim "Modeling and analysis of spacecraft battery charger systems," Ph. D. Dissertation, VPI\&SU, 1991.

[33] D. M. Sable, "Optimization of space craft battery charger/discharger systems," Ph. D. Dissertation, VPI\&SU, 1991.

[34] F. Caricchi, F. Crescimbini, G. Noia, and D. Pirolo, "Experimental study of a bidirectional dc-dc converter for the dc link voltage control and the regenerative braking in PM motor drives devoted to electrical vehicles," in Proc. IEEE APEC, Orlando, FL, Feb. 1994, pp. 381-386.

[35] K. Asano, Y. Inaguma, H. Ohtani, E. Sato, M. Okamua, and S. Sasaki, "High performance motor drive technologies for hybrid vehicles," in Proc. of PCC, Nogoya, Japan, April 2007, pp. 1584-1589.

[36] S. Aso, M. Kizaki, and Y. Nonobe, "Development of fuel cell hybrid vehicles in Toyota," in Proc. of PCC, Nogoya, Japan, April 2007, pp. 1606-1611.

[37] X. Huang, T. Nergaard., J.-S. Lai, X. Xu, and L. Zhu, "A DSP based controller for high-power interleaved boost converters," in Proc. IEEE APEC, Miami, FL, Feb. 2003, pp. 327-333.

[38] J. S. Batchvarov, J. L. Duartek, and M. A. M. Hendrix,
"Interleaved converters based on hysteresis current control," in Proc. IEEE PESC, Galway Ireland, June 2000, pp. 655-661.

[39] O. Garcia, P. Zumel, A. de Castro, and J. A. Cobo, "Automotive dc-dc Bidirectional Converter Made with Many Interleaved Buck Stages," IEEE Trans. Power Electron., vol. 21, May 2006, pp. 578-586.

[40] Y. Zhang and P. C. Sen, "A New Soft-Switching Technique for Buck, Boost, and Buck-Boost Converters," IEEE Trans. Ind. Appl., vol. 39, Nov./Dec. 2003, pp. 1775-1781.

[41] K. Wang, C. Lin, L. Zhu, D. Qu, F. Lee, and J. Lai, "Bi-directional DC to DC converters for fuel cell systems," in Proc. IEEE workshop Power Electronics in Transportation, Dearborn, MI, USA, Oct. 1998, pp. 47-51.

[42] L. Zhu, "A novel soft-commutating isolated boost full-bridge ZVS- PWM DC-DC converter for bi-directional high power applications," in Proc. IEEE Power Electronics Specialists Conference (PESC'04), Aachen, Germany, Jun. 2004, pp. 2141 2146. BIBLIOGRAPHY 287.

[43] S. Jang, T. Lee, W. Lee, and C. Won, "Bi-directional DC-DC converter for fuel cell generation system," in Proc. IEEE Power Electronics Specialists Conference (PESC'04), Aachen, Germany, Jun. 2004, pp. 4722-4728.

[44] R. Gopinath, S. Kim, J. H. Hahn, P. N. Enjeti, M. B. Yeary, and J. W. Howze, "Development of a low cost fuel cell inverter system with DSP control," IEEE Trans. Power Electron., vol. 19, no. 5, pp. 1256-1262, Sep. 2004.

[45] Y. Song and P. Enjeti, "A high frequency link direct DC-AC converter for residential fuel cell power systems," in Proc. IEEE Power Electronics Specialists Conference (PESC'04), Aachen, Germany, Jun. 2004, pp. 4755-4761.

[46] A. M. Tuckey and J. N. Krase, "A low-cost inverter for domestic fuel cell applications," in Proc. IEEE Power Electronics Specialists Conference (PESC'02), Cairns, Jun. 2002, pp. 339-346.

[47] Zh. Sun et all "A Novel Active Power Quality Compensator Topology for Electrified Railway" Power Electronics IEEE Trans. 2004.

[48] P. C. Tan et al. "A Robust Multilevel Hybrid Compensation System for $25 \mathrm{kV}$ Electrified Railway Application" Power Electronics IEEE T. 2004.

[49] L. Battistelli "Two-phase Controlled Compensator for Alternating Current Quality Improvement of Electrified Railway Systems" Electric Power Applications IEE Trans. 2006.

[50] P. C Tan et al. "Optimal Impedance Termination of $25 \mathrm{kV}$ Electrified Railway System for Improved Power Quality" Power Delivery IEEE Trans 2005.

[51] H. Lee et al. "Harmonic Analysis of Korean High-Speed Railway Using the Eight-Port Representation Model" Power Delivery IEEE Trans. 2006.

[52] G. W. Chang et al. "Modeling Characteristics of Harmonic Current Generated by High-Speed Railway Traction Drive Converters" Power Delivery IEEE Trans 2004.

[53] S. H. Lee "Analysis of Catrnary Voltage of an AT-Fed HSR System" Vehicular Technology IEEE Trans. 2004.

[54] T. H. Chen et al. "Criteria Estimate Voltage Unbalance due to High Speed Railway Demands” Power Systems IEE Trans. 1994. 